\title{
Expression of the phospho- $\beta$-glycosidase Arbz from Lactobacillus delbrueckii subsp. lactis in Lactobacillus helveticus: substrate induction and catabolite repression
}

\author{
Beate A. Weber, Jürgen R. Klein and Bernhard Henrich \\ Author for correspondence: Bernhard Henrich. Tel: +49 631 2052347. Fax: +49 6312053799. \\ e-mail: henrich@rhrk.uni-kl.de
}

Universität Kaiserslautern, Fachbereich Biologie, Abteilung Mikrobiologie, PO Box 3049, D-67653 Kaiserslautern, Germany

\begin{abstract}
ArbZ from Lactobacillus delbrueckii subsp. lactis was previously shown to enable utilization of the $\beta$-glucoside arbutin by Escherichia coli. The arbZ gene was cloned and expressed in the industrially used $\beta$-glucoside-negative strain Lactobacillus helveticus 3036(62). The transformants were able to ferment not only arbutin, but also cellobiose, salicin and methyl- $\beta$-glucoside (M/GIC). Cleavage of $\beta$-glucosides by the transformants depended on the integrity of the cytoplasmic membrane, whereas in cell-free extracts only $\mathrm{C}_{6}$-phosphorylated substrates were hydrolysed. This suggested that ArbZ is a phospho- $\beta$-glycosidase. ArbZ activity in transformants of $L b$. helveticus was subject to substrate induction mediated by the $\beta$-glucosides arbutin, salicin and M/GIC, whereas cellobiose or the $\beta$-galactoside lactose had no inducing effect. Northern blot analysis proved that induction by M/GIc was due to enhanced transcription of arbZ. Catabolite repression of arbZ induction was observed with glucose, mannose, fructose and galactose. The induction kinetics observed in the presence of these sugars indicated that at least two different mechanisms are operative in catabolite repression of arbZ in Lb. helveticus.
\end{abstract}

Keywords: Lactobacillus delbrueckii, ArbZ phospho- $\beta$-glycosidase, substrate induction, catabolite repression

\section{INTRODUCTION}

Lactic acid bacteria are indispensable for the manufacture of fermented foods, especially of dairy products. Their metabolism and genetics have been extensively studied over the past years. Growth of lactic acid bacteria depends on the availability of appropriate carbohydrates and, since lactose is the predominant sugar in milk, two pathways for lactose utilization by lactic acid bacteria have been thoroughly investigated (deVos, 1996). One of them, which is operative in lactococci and in several lactobacilli, relies on lactose transport by the phosphotransferase system (PTS), and the resulting lactose 6-phosphate is hydrolysed by phospho(P)- $\beta$-galactosidase (deVos et al., 1990). The second pathway has been observed in Leuconostoc lactis, Streptococcus thermophilus and a number of

Abbreviations: $\mathrm{M} \beta \mathrm{GlC}$, methyl- $\beta$-glucoside; oNPGal, o-nitrophenyl $\beta$-Dgalactopyranoside; oNPGalP, oNPGal 6-phosphate; pNPGIc, $p$-nitrophenyl $\beta$-D-glucopyranoside; PTS, phosphotransferase system. thermophilic lactobacilli where lactose is transported via a specific permease and then cleaved by $\beta$-galactosidase (David et al., 1992; Vaughan et al., 1996).

Utilization of $\beta$-glucosides by bacteria occurs through pathways similar to those described for the $\beta$-galactoside lactose. In most cases, $\beta$-glucosides are hydrolysed by extracellular or cell-wall-associated $\beta$-glucosidases (Gräbnitz \& Staudenbauer, 1988; González-Candelas et al., 1989). If uncleaved $\beta$-glucosides are transported into the cells, this is achieved either by specific permeases (Helaszek \& White, 1991) or via the PTS with subsequent hydrolysis of the resulting $\mathrm{P}-\beta$-glucosides into glucose 6-phosphate and the respective aglycons (Schnetz et al., 1987; Tobisch et al., 1997).

Connections between the metabolism of $\beta$-glucosides and $\beta$-galactosides were suggested by Simons et al. (1993), who observed that, in revertants of $l a c G$ deletion mutants of Lactococcus lactis, a P- $\beta$-glucosidase seemed to be responsible for their slow growth on lactose. In these revertants, the $\mathrm{P}$ - $\beta$-glucosidase was not only 
induced by cellobiose but also by lactose. Relations between $\beta$-glucoside and $\beta$-galactoside utilization may also be deduced from sequence similarities of $\mathrm{P}-\beta$ galactosidases and P- $\beta$-glucosidases which assign most of them to family I of glycosylhydrolases (Henrissat, 1991). Furthermore, several P- $\beta$-glucosidases and P$\beta$-galactosidases cleave $\mathrm{C}_{6}$-phosphorylated derivatives of both $\beta$-galactosides and $\beta$-glucosides (Witt et al., 1993; Simons et al., 1993).

Little is known about $\beta$-glucoside metabolism in lactobacilli. For Lactobacillus plantarum, a glucose-repressible P- $\beta$-glucosidase gene was recently identified (Marasco et al., 1998). We previously achieved cloning and sequence analysis of arbZ from Lactobacillus delbrueckii subsp. lactis. ArbZ seems to be involved in $\beta$ glucoside metabolism since it conferred the ability to utilize the $\beta$-glucoside arbutin when expressed in Escherichia coli (Weber et al., 1998). Here we report on the expression and control of arbZ in Lactobacillus helveticus strain 3036(62), which is used in industrial food production.

\section{METHODS}

Bacterial strains and media. E. coli ER1562 (Raleigh et al., 1988) was grown in LB medium (Sambrook et al., 1989) at $37^{\circ} \mathrm{C}$. When appropriate, chloramphenicol $\left(10 \mu \mathrm{g} \mathrm{ml}^{-1}\right)$ was added. Fermentation of arbutin was screened on eosine methylene blue agar (EMB agar base; Difco) supplemented with $0.5 \%$ arbutin (EMB-arbutin agar). Positive colonies were identified by their dark-blue colour on this medium. $L b$. delbrueckii subsp. lactis DSM 7290 (Süddeutsche Forschungsanstalt für Milchwirtschaft, Weihenstephan) and $L b$. helveticus 3036(62) (Bundesanstalt für Milchforschung, Kiel) were grown in MRS broth (De Man et al., 1960) at $37^{\circ} \mathrm{C}$. When appropriate, chloramphenicol $\left(5 \mu \mathrm{g} \mathrm{ml}^{-1}\right)$ was added. Fermentation of carbohydrates ( $1 \%$ final concentration) was tested in sugar fermentation broth (SFB), which is MRS broth with $0 \cdot 2 \%$ (instead of $0 \cdot 8 \%$ ) meat extract and without glucose. After $24-48 \mathrm{~h}$ cell growth in this medium, acidification was checked by addition of chlorphenol red $\left(0 \cdot 1 \mathrm{mg} \mathrm{ml}^{-1}\right.$ final concentration). Cleavage of aesculin was screened on aesculiniron agar, which is aesculin broth (Merck), supplemented with $15 \mathrm{~g}$ agar $\mathrm{l}^{-1}$ and $1 \mathrm{~g}$ Tween $80 \mathrm{l}^{-1}$. Positive colonies were identified on this agar by their brown colour due to the formation of an aesculetin-Fe(III) complex.

Recombinant DNA techniques. Restriction endonucleases and nucleic acid modifying enzymes (Roche) were used as recommended by the manufacturer. Cloning techniques were performed according to Sambrook et al. (1989). Plasmids were prepared from $L b$. helveticus as described by Anderson \& McKay (1983). Electroporation of E. coli was performed as described by Dower et al. (1988), and Lb. helveticus was electroporated according to Bhowmik \& Steele (1993).

For PCR amplification of a $817 \mathrm{bp}$ arbZ fragment (nt 1293-2109, accession number Z86115), the primers 5'-CCACAATATCGAGCTCACCGCACCCAAC-3' and 5'-GCCGGCGATATCCCATGGAGTGAAGTCG-3' were used. The cat gene (encoded by pGK12 and pBW121) was amplified with the primers 5'-AAAGCACCCATTAGTTCAACAAACG-3' and 5'-AACCTTCTTCAACTAACGGGGCAGG-3'. PCR reactions were carried out with Taq DNA polymerase as recommended by the supplier (Appligene). The temperature profile $(25$ cycles $)$ used for both amplifications was $1 \mathrm{~min}$ at $95^{\circ} \mathrm{C}$ (denaturation), $1 \mathrm{~min}$ at $60{ }^{\circ} \mathrm{C}$ (annealing) and $1 \mathrm{~min}$ at $72{ }^{\circ} \mathrm{C}$ (elongation). As templates, $100 \mathrm{ng}$ total bacterial DNA isolated with the Genomix scale-up kit (Talent, Triest) or 10 ng plasmid DNA (controls) was used.

Construction of pBW121. A $1474 \mathrm{bp} \mathrm{AccI-XmaIII} \mathrm{fragment,}$ containing $a r b Z$ and the $3^{\prime}$-end of the preceding $a r b X$ gene ('arbX) (Weber et al., 1998), was made blunt at the XmaIII site with Klenow fragment of E. coli DNA polymerase I and inserted between the HpaII and SnaBI sites of the vector pGK12 (Kok et al., 1984). The resulting plasmid, pBW121, was initially identified after transformation of E. coli ER1562 by screening on EMB-arbutin agar and then used to transform Lb. helveticus.

Northern and Southern hybridizations. For Northern blot analyses, total RNA $(4 \mu \mathrm{g})$, isolated with the RNeasy total RNA kit (Qiagen), was electrophoretically separated and blotted as described previously (Henrich et al., 1990). A 817 bp PCR-amplified arbZ probe was non-radioactively labelled, hybridized to the blotted RNA, and detected by using a digoxigenin DNA labelling and detection kit (Roche) as recommended by the supplier.

For Southern blot analyses, total DNA from Lb. helveticus 3036(62) was isolated using the Genomix scale-up kit. DNA fragments $(2 \mu \mathrm{g})$, obtained by restriction with HindIII or ClaI, were separated on $0.7 \%$ agarose gels and blotted to nylon membranes (Sambrook et al., 1989). The 817 bp arbZ probe was fluorescently labelled, hybridized to the blotted DNA fragments, and detected as recommended by the manufacturer (Amersham) of the ECL random prime labelling and detection system used.

In vivo assay of $\boldsymbol{\beta}$-glycosidase activity. Strains of $L b$. helveticus were grown in SFB supplemented with appropriate sugars. At $\mathrm{OD}_{600} 0 \cdot 6-0 \cdot 8$, cells from $2 \mathrm{ml}$ aliquots of the cultures were collected by centrifugation, washed twice with $1 \mathrm{ml} \mathrm{Z}$-buffer (Miller, 1972), and resuspended in $1.5 \mathrm{ml}$ of the same buffer. When appropriate, cells were permeabilized by the addition of chloroform to a final concentration of $14 \%(\mathrm{v} / \mathrm{v})$. Three hundred microlitres of these suspensions was mixed with $10 \mu \mathrm{l}$ of the respective substrates $\left(10 \mathrm{mg} \mathrm{ml}^{-1}\right.$ in Z-buffer) and incubated at $37^{\circ} \mathrm{C}$. When using the chromogenic substrates $p$-nitrophenyl $\beta$-D-glucopyranoside ( $p$ NPGlc) (Fluka) and $o$-nitrophenyl $\beta$-D-galactopyranoside (oNPGal) (Sigma), the reactions were stopped by the addition of $300 \mu \mathrm{l} 2 \mathrm{M} \mathrm{Na}_{2} \mathrm{CO}_{3}$ as soon as a light-yellow colour had developed. Cells were subsequently removed by centrifugation, and the amounts of liberated $p$ - or $o$-nitrophenol were determined photometrically at $410 \mathrm{~nm}$ or $420 \mathrm{~nm}$, respectively. Cleavage of salicin or arbutin was assayed as described by Schaefler (1967). Each reaction was repeated at least four times. Units of ArbZ activity were expressed as nmol of the aglycons liberated from the respective substrates $\mathrm{min}^{-1}$. Specific activities were calculated as units per $\mathrm{OD}_{600}$ unit of the cell suspensions used in the assays.

Assay of (phospho) $\beta$-glycosidase activity in cell-free extracts. To prepare crude cell extracts, $L b$. helveticus strains were cultivated in SFB supplemented with appropriate sugars. At $\mathrm{OD}_{600} 0 \cdot 4-0 \cdot 7$, cells were pelleted from $20 \mathrm{ml}$ aliquots by centrifugation, washed twice with Z-buffer, and resuspended in $1.7 \mathrm{ml} \mathrm{Z}$-buffer $(\mathrm{mg} \text { cell wet } \mathrm{wt})^{-1}$. After addition of $2.5 \mathrm{ml}$ glass beads $(\varnothing 0.18 \mathrm{~mm})(\mathrm{mg} \text { cell wet } \mathrm{wt})^{-1}$, the bacteria were disrupted by shaking in a Vibrogen cell mill (Bachhofer) for $20 \mathrm{~min}$ at $4{ }^{\circ} \mathrm{C}$ at a frequency of $70 \mathrm{~Hz}$. The samples were 
subsequently diluted by the addition of Z-buffer $[1.5 \mathrm{ml}(\mathrm{mg}$ cell wet $w t)^{-1}$ ] and thoroughly mixed. Cell debris and glass beads were removed by centrifugation for $10 \mathrm{~min}$ at $14800 \mathrm{~g}$ and $4{ }^{\circ} \mathrm{C}$, and the protein concentration in the supernatants (cell-free extracts) was determined with Coomassie blue (Spector, 1978). To determine the activity of $\beta$-glycosidases and P- $\beta$-glycosidases in cell extracts (Weber et al., 1998), the chromogenic substrates oNPGal, oNPGal 6-phosphate (oNPGalP) (Sigma) and pNPGlc (Fluka) were used. Each reaction was repeated at least three times. Enzyme units were defined as nmol nitrophenol liberated $\min ^{-1}$, and specific activities were expressed in units (mg protein $)^{-1}$.

\section{RESULTS AND DISCUSSION}

\section{Cloning of arbZ in Lb. helveticus}

The arbZ gene from $L b$. delbrueckii subsp. lactis DSM 7290 was cloned in the industrially used $L b$. helveticus strain 3036(62). We chose Lb. helveticus as a host for several reasons. (i) In contrast to Lb. delbrueckii subsp. lactis DSM 7290, strain 3036(62) is readily accessible to electrotransformation. (ii) Strain 3036(62) is definitively unable to ferment $\beta$-glucosides, and it does not spontaneously release $\beta$-glucoside-positive mutants during prolonged selection on $\beta$-glucosides as has been reported for E. coli (Parker \& Hall, 1990; Hall \& Xu, 1992). On the other hand, arbZ mutants of $L b$. delbrueckii subsp. lactis DSM 7290 are difficult to construct due to its resistance to transformation, and it is not known whether additional systems for $\beta$-glucoside utilization are present in this strain. The occurrence of at least two $\beta$-glucoside utilization systems has been reported for $L c$. lactis (Simons et al., 1993). (iii) Lb. helveticus is more closely related to $L b$. delbrueckii than are other transformable lactic acid bacteria, such as Lactococcus or Lactobacillus casei. In addition, all of the transformable Lactococcus and Lactobacillus strains for which characterized mutants in the catabolite control system exist are $\beta$-glucoside-positive.

$L b$. helveticus 3036(62) was transformed with the arbZcontaining plasmid $\mathrm{pBW} 121$, or with the vector pGK12 as a control. Of about 100 chloramphenicol-resistant clones obtained from two independent transformations with pBW121, 24 were tested for utilization of the $\beta$-glucoside arbutin in SFB-arbutin. Of these transformants, only four (two from each transformation) were stably positive for arbutin fermentation. No arbutin-fermenting clones were detected among a similar number of pGK12 transformants, even after prolonged incubation.

Attempts to prepare plasmids from pBW121 transformants and pGK12 transformants (Anderson \& McKay, 1983) did not yield electrophoretically detectable amounts of plasmid DNA. In a more sensitive assay, we used the material obtained from these preparations to retransform the restriction/ modification-deficient E. coli strain ER1562. As estimated from control experiments with known concentrations of pBW121 and pGK12, fresh transformants of $L b$. helveticus, after growth in chloramphenicol-con- (a)

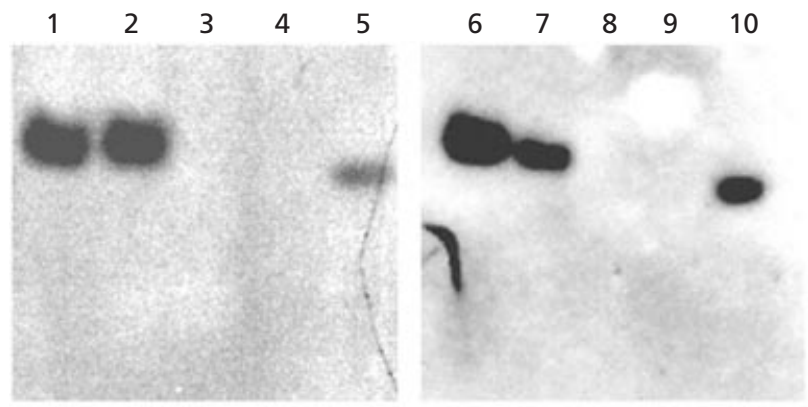

(b)

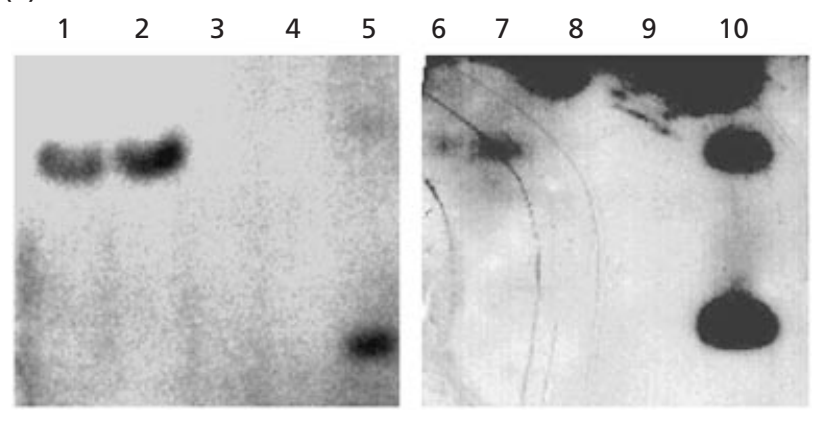

Fig. 1. Southern blot analysis of DNA from $L b$. helveticus transformants. Plasmid pBW121 (lanes 5, 10) and total DNA from four arbutin-positive $L b$. helveticus 3036(62)(pBW121) clones (lanes 1, 2, 6, 7) and from four $L b$. helveticus 3036(62)(pGK12) transformants (lanes 3, 4, 8, 9) were restricted with Clal (a) or HindIII (b) and blotted to nylon membranes. Blots were probed with a fluorescently labelled $817 \mathrm{bp}$ fragment of $a r b Z$.

taining MRS broth for $12 \mathrm{~h}$, contained less than one plasmid copy per cell. More than $50 \%$ of these plasmids were clearly reduced in size as compared with pBW121 and pGK12, respectively. These effects pointed to structural instability of pBW121 and pGK12 in the $L b$. helveticus host, since both plasmids were structurally stable during propagation in E. coli. After repeated subculturing of Lb. helveticus 3036(62)(pBW121) and Lb. helveticus 3036(62)(pGK12), no plasmid DNA at all was detectable in the E. coli retransformation assay.

When total DNA prepared from subcultures of each of the four arbutin-positive pBW121 transformants was used as template for PCR, arbZ as well as the plasmidencoded cat gene could be amplified, whereas in pGK12 transformants only cat was detectable. The presence of arbZ in the arbutin-utilizing $L b$. helveticus 3036(62)(pBW121) clones was also verified by Southern blot analysis (Fig. 1). An arbZ probe gave a single hybridization signal with total DNA from each of the four clones, digested with restriction enzymes (HindIII or ClaI) which do not cut within arbZ. No signals were obtained with DNA from pGK12 transformants. When ClaI- or HindIII-restricted plasmid pBW121 (one ClaI site, no HindIII site) was probed, the positions of arbZspecific signals were clearly different from those observed with total DNA from the arbutin-positive 
Table 1. ArbZ activities of transformants of $L b$. helveticus grown with different carbon sources

SD, Standard deviation calculated from at least three independent measurements; ND, not determined.

\begin{tabular}{|c|c|c|c|c|c|c|}
\hline \multirow[t]{2}{*}{$\begin{array}{l}\text { Carbohydrate in } \\
\text { growth medium }\end{array}$} & \multirow[t]{2}{*}{$\begin{array}{l}\text { Lb. helveticus } \\
\text { transformed with: }\end{array}$} & \multicolumn{2}{|c|}{$\begin{array}{l}\text { In vivo with } p \text { NPGlc } \\
\left(\mathrm{U} \text { per } \mathrm{OD}_{600} \text { unit } \pm \mathrm{SD}\right)\end{array}$} & \multicolumn{3}{|c|}{$\begin{array}{c}\text { In cell-free extracts } \\
{\left[\mathrm{U}(\mathrm{mg} \text { protein })^{-1} \pm \mathrm{SD}\right] \text { with: }}\end{array}$} \\
\hline & & -Chloroform & + Chloroform & $p$ NPGlc & oNPGal & $o$ NPGalP \\
\hline \multirow[t]{2}{*}{ Glucose } & pBW121 & $0 \cdot 2 \pm 0 \cdot 05$ & $0 \cdot 1 \pm 0 \cdot 04$ & $5 \cdot 3 \pm 1 \cdot 3$ & $1 \cdot 29 \pm 0 \cdot 3$ & $4 \cdot 0 \pm 1 \cdot 0$ \\
\hline & pGK12 & $0 \cdot 02 \pm 0 \cdot 006$ & $0 \cdot 025 \pm 0 \cdot 007$ & $0 \cdot 2 \pm 0 \cdot 06$ & $1 \cdot 44 \pm 0.36$ & $0 \cdot 8 \pm 0 \cdot 23$ \\
\hline \multirow[t]{2}{*}{ Lactose } & pBW121 & $0 \cdot 42 \pm 0.09$ & $0 \cdot 33 \pm 0 \cdot 09$ & $6 \cdot 1 \pm 1 \cdot 5$ & $732 \pm 95$ & $537 \pm 70$ \\
\hline & pGK12 & $0 \cdot 04 \pm 0.008$ & $0 \cdot 055 \pm 0 \cdot 014$ & $0 \cdot 4 \pm 0 \cdot 1$ & $728 \pm 93$ & $524 \pm 64$ \\
\hline \multirow[t]{2}{*}{ Xylose } & pBW121 & $1 \cdot 0 \pm 0 \cdot 25$ & $\mathrm{ND}$ & $5 \cdot 1 \pm 1 \cdot 15$ & $12 \cdot 3 \pm 3$ & $14 \cdot 5 \pm 3 \cdot 6$ \\
\hline & pGK12 & $0 \cdot 034 \pm 0 \cdot 01$ & ND & $0.33 \pm 0.08$ & $12 \cdot 0 \pm 2 \cdot 8$ & $9 \cdot 5 \pm 2 \cdot 4$ \\
\hline Salicin* & pBW121 & $11 \cdot 4 \pm 2 \cdot 8$ & $0 \cdot 24 \pm 0 \cdot 07$ & $9 \cdot 1 \pm 2 \cdot 3$ & $14 \cdot 2 \pm 3 \cdot 7$ & $352 \pm 50$ \\
\hline Arbutin* & pBW121 & $12 \cdot 2 \pm 3 \cdot 0$ & $0 \cdot 5 \pm 0 \cdot 11$ & ND & ND & $\mathrm{ND}$ \\
\hline
\end{tabular}

* Since transformants with pGK12 did not grow in the presence of salicin or arbutin, no activities could be determined in these cases.

pBW121 transformants (Fig. 1). This indicated that arbZ had been integrated into the chromosome of the transformants.

The vector pGK12, used to construct pBW121, has been reported to replicate in Lb. helveticus CNRZ32 (Bhowmik \& Steele, 1993). Segregational instability of this replicon, however, may be suspected from its sigma replication mode (Kiewiet et al., 1993), and structural instability of pBW121 was observed in transformants of Lb. helveticus 3036(62) (see above). We therefore suspect that chromosomal integration probably served to rescue the chloramphenicol-resistance marker during the initial selection of transformants, whereas the non-selected arbZ gene was lost in most of the clones. Recombination between the $L b$. helveticus genome and some homologous regions present in the insert or the vector part of the plasmid may be considered as a mechanism for chromosomal integration of pBW121. However, no sequences with notable homology to arbZ seem to be present in $L b$. helveticus since no arbZ-specific signals were obtained in Southern hybridizations with DNA from Lb. helveticus 3036(62)(pGK12), even under nonstringent conditions (not shown). Furthermore, PCR and plasmid analyses of Lb. helveticus 3036(62) (pGK12) transformants indicated that the unmodified vector also integrated into the chromosome. This suggested that integration did not require the plasmid-encoded 'arbXarbZ region, but probably occurred through sequences of the vector.

As $L b$. helveticus 3036(62) is not able to ferment $\beta$ glucosides and has no native (P)- $\beta$-glucosidase (see Table 1), the presence of a functional arbZ homologue in this strain can be excluded. So, even if weak homology between the 'arbX-arbZ region in pBW121 and the $L b$. helveticus chromosome was assumed, integration into a non-functional arbZ-like sequence of the host would most probably lead to inactivation and disruption of the plasmid-encoded arbZ gene. This was excluded by measurements of ArbZ activity in the transformants (see
Table 1) and by demonstrating the integrity of $a r b Z$ in PCR and Northern blot (Fig. 2b) analyses.

In addition to ordinary recombination, other pathways allowing for low-frequency DNA integration in the absence of obvious sequence homology seem to be operative in lactic acid bacteria (Rixon et al., 1990; Leenhouts et al., 1990).

\section{Fermentation of $\beta$-glucosides by $L b$. helveticus 3036(62)(pBW121)}

Our previous studies showed that arbZ, when expressed in E. coli, allowed for utilization of arbutin, whereas fermentation of other $\beta$-glucosides could not be detected (Weber et al., 1998). With the arbutin-positive $L b$. helveticus 3036(62) (pBW121) clones a different substrate pattern was observed. In SFB, not only arbutin, but also the $\beta$-glucosides salicin and cellobiose, and, with a lower efficiency, methyl- $\beta$-glucoside (M $\beta$ Glc) (Sigma), were utilized as carbon sources and converted to acidic fermentation products. The growth rates ranged between 0.003 and $0.004 \mathrm{~min}^{-1}$ for cellobiose, salicin and arbutin and was $0.0012 \mathrm{~min}^{-1}$ for $\mathrm{M} \beta$ Glc. Cleavage of arbutin and salicin was verified by assaying the hydrolytic activity of the transformants towards these substrates. The arbutin-positive Lb. helveticus $3036(62)$ (pBW121) clones, in addition, were able to cleave aesculin, as indicated by a positive reaction on aesculin-iron agar. The transformants with pGK12, in contrast, were not able to grow in the presence of arbutin, salicin, cellobiose or $\mathrm{M} \beta \mathrm{Glc}$ or to hydrolyse arbutin, salicin or aesculin. When glucose or the $\beta$ galactoside lactose was used as carbon source, no differences in the growth rates $\left(0.0056 \mathrm{~min}^{-1}\right.$ for glucose, $0.0053 \mathrm{~min}^{-1}$ for lactose) were observed between transformants carrying pBW121 or pGK12, respectively. This indicated that the ability of Lb. helveticus to utilize $\beta$ glucosides depended on the presence of the cloned $\operatorname{arbZ}$ gene. 
(a)

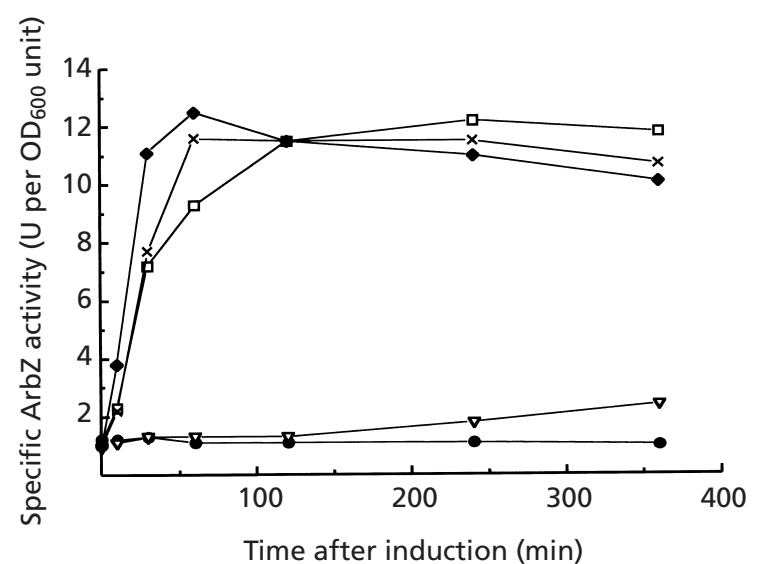

(b)

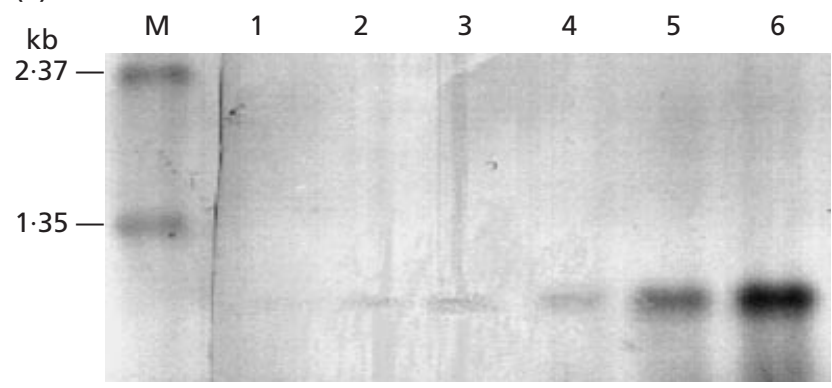

Fig. 2. Substrate induction of ArbZ in arbutin-positive $L b$. helveticus 3036(62)(pBW121) transformants. (a) Cells were grown in SFB-xylose supplemented with chloramphenicol. At $\mathrm{OD}_{600} 0.4-0.5$ (time $=0 \mathrm{~min}$ ), no $\beta$-glucoside $(\bullet)$, arbutin $(\bullet)$, salicin $(x), \quad M \beta G l c(\square)$ or cellobiose $(\nabla)$ (1 mM final concentration) was added. Arbz activity was determined in culture aliquots by the in vivo assay with pNPGIc as a substrate. Induction kinetics obtained with two independently isolated arbutin-positive $L b$. helveticus 3036(62)(pBW121) clones were almost identical. (b) Total RNA, prepared from aliquots of a $M \beta G I c-i n d u c e d$ culture $0 \mathrm{~min}$ (1), $10 \mathrm{~min}(2), 30 \mathrm{~min}$ (3), $60 \mathrm{~min}$ (4), $120 \mathrm{~min}$ (5) and $240 \mathrm{~min}$ (6) after induction, was used for Northern hybridization with a digoxigenin-11-dUTP-labelled $817 \mathrm{bp}$ fragment of arbZ. A 0.24-9.5 kb RNA ladder (Gibco-BRL) was used as a size standard (M).

\section{arbZ confers P- $\beta$-glycosidase activity}

Expression of $a r b Z$ was clearly detectable in the in vivo assay. After growth with glucose, lactose or xylose, each of the four arbutin-positive L $b$. helveticus 3036(62)(pBW121) clones showed 10-30-fold higher activities towards the $\beta$-glucoside $p$ NPGlc than the respective pGK12 transformants (Table 1). Permeabilization of the cytoplasmic membrane by chloroform prior to the assay resulted in a decrease of ArbZ activity, which was most pronounced (45-fold) after growing the cells in the presence of salicin. This suggested that ArbZ activity towards $\beta$-glycosides required the integrity of the cytoplasmic membrane. As possible explanations, membrane association of ArbZ or its requirement for phosphorylated substrates were considered. Since membrane location of ArbZ was unlikely (Weber et al., 1998), we chose the $\mathrm{C}_{6}$ phosphorylated $\beta$-galactoside $o$ NPGalP for activity tests with cell-free extracts. This substrate seemed appropriate, as chromogenic derivatives of phosphorylated $\beta$ glucosides were not available and cleavage of oNPGalP had previously been reported for P- $\beta$-glucosidases of $E$. coli (Witt et al., 1993) and Lc. lactis (Simons et al., 1993). Cell-free extracts prepared from the arbutin-positive $L b$. helveticus 3036(62)(pBW121) clones, after growth with glucose or xylose, showed 5- or 1.5-fold higher activities towards oNPGalP than those from pGK12 transformants, which demonstrated that ArbZ contributed to cleavage of this substrate. Notably, extracts from salicin-grown cells were more than 20 -fold less active towards $p$ NPGlc or oNPGal than towards oNPGalP (Table 1). This clearly indicated that ArbZ was able to efficiently hydrolyse the phosphorylated substrate in the absence of a functional cytoplasmic membrane. We therefore classified ArbZ as a P- $\beta$-glycosidase.

After growth with lactose, extracts of transformants with both pBW121 or pGK12 contained more than 100fold higher oNPGalP-hydrolysing activities, as compared with extracts of glucose-grown cells (Table 1). This suggested that, under these conditions, the activity of ArbZ towards oNPGalP was concealed by a native, lactose-inducible P- $\beta$-galactosidase of $L b$. helveticus 3036(62). As deduced from in vitro assays (Table 1) and in vivo assays (not shown) with oNPGal after growth on lactose, this strain in addition has a native $\beta$ galactosidase. Coincidence of both activities in the same strain has previously been reported for other lactic acid bacteria (Premi et al., 1972; Okamoto \& Morichi, 1979).

Since $L b$. helveticus, in the absence of cloned arbZ, did not grow at all with salicin as carbon source, we could not exclude that high oNPGalP-hydrolysing activities in extracts of salicin-grown pBW121 transformants were partly due to induction of the native P- $\beta$-galactosidase by salicin. This, however, seemed unlikely, since induction of $o$ NPGalP cleavage by another $\beta$-glucoside, $\mathrm{M} \beta \mathrm{Glc}$, also required the expression of $\operatorname{arbZ}$, and no induction of the native P- $\beta$-galactosidase by $\mathrm{M} \beta \mathrm{Glc}$ was observed in this case (not shown).

\section{Induction of ArbZ activity by $\beta$-glucosides}

ArbZ activity of the arbutin-positive $L b$. helveticus 3036(62)(pBW121) clones depended on the carbon source in the growth medium (Table 1). When salicin or arbutin was used, the in vivo activities were about 10fold higher than in the presence of xylose and more than 25 -fold higher than in the presence of lactose. This indicated that ArbZ is subject to substrate induction, which is a common feature in bacterial $\beta$-glucoside catabolism (Schnetz \& Rak, 1988; Krüger et al., 1996; Woodward \& Wiseman, 1982).

Two independently isolated arbutin-positive $L b$. helveticus 3036(62)( $\mathrm{pBW} 121$ ) clones were grown in SFB- 

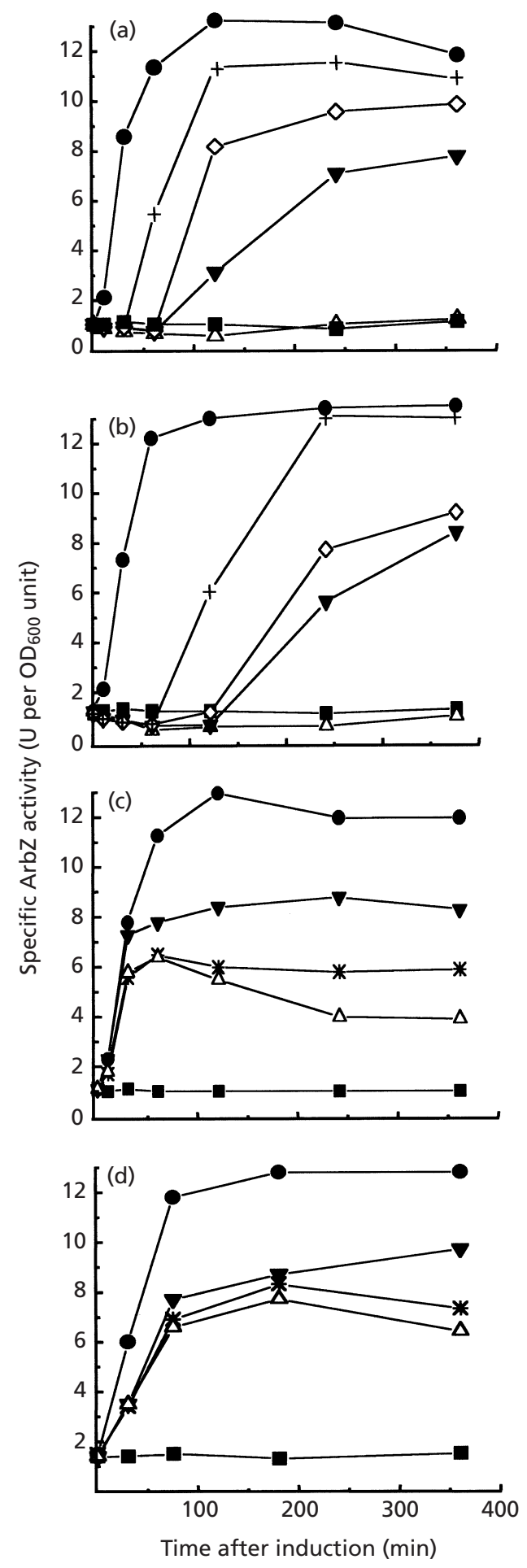

Fig. 3. Effects of hexoses on $\mathrm{M} \beta \mathrm{G}$ Glc-induced ArbZ activity. Arbutin-positive $L b$. helveticus 3036(62)(pBW121) transformants were grown in SFB-xylose supplemented with chloramphenicol. At $\mathrm{OD}_{600} 0 \cdot 4-0.5$ (time $=0 \mathrm{~min}$ ), ArbZ was induced by the addition of $\mathrm{M} \beta \mathrm{Glc}$ (1 $\mathrm{mM}$ final concentration), and simultaneously glucose (a), mannose (b), fructose (c) or galactose (d) were added. Concentrations ( $w / v)$ of the sugars were $0.3 \%(\triangle), 0.2 \%(*), 0.1 \%(\nabla), 0.075 \%(\diamond)$ and $0.035 \%$ $(+)$, respectively. To the control cultures only $\mathrm{M} \beta \mathrm{Glc}(0)$, or neither $\mathrm{M} \beta \mathrm{Glc}$ nor an additional sugar ( $\boldsymbol{\square}$ ) was added. ArbZ activity was determined by the in vivo assay with pNPGlc as a xylose, and the time courses of ArbZ induction were followed after addition of various $\beta$-glucosides. Since both clones showed very similar induction kinetics, only one set of curves is presented in Fig. 2(a). Cellobiose, although being a substrate for ArbZ, was only a poor inducer. A similar observation, previously reported for a $\beta$-glucosidase from Botryodiplodia theobromae (Woodward \& Wiseman, 1982), has been ascribed to repression by glucose, which is liberated by cleavage of cellobiose in twofold higher amounts than from other $\beta$ glucosides. Arbutin, salicin and $\mathrm{M} \beta \mathrm{G}$ Glc led to strong increase of activity within $60 \mathrm{~min}$ after their addition (Fig. 2a). Arbutin was the most potent inducer, while induction by $\mathrm{M} \beta \mathrm{Glc}$ occurred more slowly. The activities induced by arbutin and salicin slowly declined after reaching a maximum, probably due to cleavage of these $\beta$-glucosides. The inducing effect of $M \beta G$ Glc persisted longer, which is in accordance with low ArbZ activity towards $M \beta G$ lc, as concluded from growth experiments.

Total RNA, prepared from arbutin-positive $L b$. helveticus 3036(62)(pBW121) transformants after induction with $\mathrm{M} \beta \mathrm{Glc}$, was analysed in Northern hybridizations with an arbZ-specific probe. Increase of ArbZ activity after induction was found to be accompanied by simultaneous increase of a $960 \mathrm{nt}$ arbZ transcript (Fig. 2b). A similar transcript was not found in pGK12 transformants. This demonstrated that $\beta$ glucoside-dependent control of ArbZ occurs at the transcriptional level. Antitermination may be considered as a possible mechanism to enhance arbZ transcription, since several other prokaryotic systems for $\beta$-glucoside metabolism are subject to this type of control (Schnetz \& Rak, 1988; Krüger et al., 1996). The $a r b Z$ upstream sequence, however, does not contain any stem-loop structures or RAT motifs (Aymerich \& Steinmetz, 1992) typical of other transcriptional antiterminators.

We previously demonstrated that the $1474 \mathrm{bp}$ fragment of chromosomal DNA present in pBW121 contains a functional promoter between ' $a r b X$ and $a r b Z$ and a terminator downstream of $a r b Z$. These signals determined the ends of a $960 \mathrm{nt}$ arbZ transcript which we detected in Lb. delbrueckii subsp. lactis DSM 7290 after growth with arbutin or salicin (Weber et al., 1998). It should be noted that the arbZ transcripts, detected after $\mathrm{M} \beta \mathrm{Glc}$ induction of $\mathrm{Lb}$. helveticus 3036(62)(pBW121) transformants (Fig. 2b), had exactly the same size. This clearly indicated (i) that arbZ had retained its physical integrity during integration into the Lb. helveticus genome and (ii) that substrate induction actually occurred at the native arbZ promoter and not at a promoter which might be located adjacent to the $\operatorname{arbZ}$ integration site.

substrate. The catabolite repression effects observed with two independently isolated arbutin-positive $L b$. helveticus 3036(62)(pBW121) clones were almost identical. 


\section{Catabolite control of ArbZ}

After growth with glucose, whole cells or extracts of the four arbutin-positive Lb. helveticus 3036(62)(pBW121) clones showed 5- or 3.6-fold lower activities towards $p$ NPGlc or oNPGalP, respectively, than after growth with xylose (Table 1). ArbZ therefore seemed to be subject to catabolite repression in these transformants. To verify this, different hexoses were added to cultures of two independently isolated arbutin-positive $L b$. helveticus 3036(62)(pBW121) clones grown in SFBxylose, and simultaneously arbZ was induced with M $\beta$ Glc. As shown in Fig. 3, each of the sugars tested (glucose, fructose, mannose, galactose) had an inhibitory effect on induction of ArbZ activity. There were, however, significant differences in the time courses of ArbZ induction, which allowed for classifying the sugars into two groups. (i) Inhibition by glucose and mannose was very effective. In the presence of $0 \cdot 3 \%$ of these sugars no induction of ArbZ was observed within $7 \mathrm{~h}$. The repressive effect was detectable immediately after addition of the sugars and resulted in a time delay of induction. The length of this delay was proportional to the concentration of the respective sugars whereas the final ArbZ activities were inversely related. This effect was more pronounced for glucose than for mannose (Fig. 3a, b). The immediate repression effect of glucose and mannose may be explained by a transportdependent control mechanism such as inducer exclusion (Ye \& Saier, 1996) or involvement of a transcriptional regulator with a PTS regulation domain (PRD) (Stülke et al., 1998). It is also reminiscent of 'transient repression', previously described for the lac operon of $E$. coli (Tyler \& Magasanik, 1969). (ii) Inhibition by fructose and galactose was more moderate; distinct ArbZ induction was still observed in the presence of $0.3 \%$ of the sugars (Fig. 3c, d). In contrast to glucose and mannose, the inhibitory effect of galactose and fructose only became visible about $60 \mathrm{~min}$ after addition of the sugars and resulted in flattening of the induction curves. Such effects would be expected for a repression mechanism that depends on formation of specific intermediates during catabolism of the respective sugars. The maximum ArbZ activities after addition of fructose or galactose showed a similar dependence on sugar concentrations as observed for glucose and mannose.

In conclusion, it appeared that, depending on the nature of the repressing sugars, at least two distinct mechanisms are involved in catabolite repression of ArbZ. Similar observations have been reported for the P- $\alpha$-glucosidase TreA of Bacillus subtilis (Helfert et al., 1995) and for a $\beta$-galactosidase from Staphylococcus xylosus (Egeter \& Brückner, 1996). Although catabolite control in Grampositive bacteria is often mediated by the transcription regulator CcpA (Saier et al., 1996), several other mechanisms are known. These include inducer exclusion (Ye \& Saier, 1996), inducer expulsion (Reizer, 1989) and involvement of a glucose kinase (Wagner et al., 1995) or proteins with PRDs (Stülke et al., 1998).

CcpA, through its interaction with intermediates of carbohydrate catabolism, is able to respond not only to glucose but also to a number of other sugars (Saier et al., 1996). Therefore, repression of ArbZ by each of the four sugars tested might be a reflection of a CcpA-related control mechanism. This option is further supported by the presence of a palindromic sequence $\left(5^{\prime}\right.$-TGAGAACGATGACT-3') upstream of arbZ (Weber et al., 1998), which overlaps with the first nucleotide of the putative -35 region and matches the consensus sequence of catabolite responsive elements (cre) (Weickert \& Chambliss, 1990) in 13 out of 14 positions. The cre sequence is known to interact with CcpA in a number of catabolite-controlled operons, and CcpA usually has a repressive effect if (as in the case of arbZ) cre overlaps the respective promoters or is located downstream of them (Weickert \& Chambliss, 1990; Hueck et al., 1994; Saier et al., 1996). It is therefore tempting to speculate that cre and CcpA homologues are involved in catabolite repression of $\operatorname{arbZ}$.

\section{ACKNOWLEDGEMENTS}

We thank Bernd Winkelmann for the synthesis of oligonucleotides. This work was in part supported by the Bundesministerium für Forschung und Technologie (grant 0319281B).

\section{REFERENCES}

Anderson, D. G. \& McKay, L. L. (1983). Simple and rapid method for isolating large plasmid DNA from lactic streptococci. Appl Environ Microbiol 46, 549-552.

Aymerich, S. \& Steinmetz, M. (1992). Specificity determinants and structural features in the RNA target of the bacterial antiterminator proteins of the BglG/SacY family. Proc Natl Acad Sci U S A 89, 10410-10414.

Bhowmik, T. \& Steele, J. L. (1993). Development of an electroporation procedure for gene disruption in Lactobacillus helveticus CNRZ32. J Gen Microbiol 139, 1433-1439.

David, S., Stevens, H., van Riel, M., Simons, G. \& deVos, W. M. (1992). Leuconostoc lactis $\beta$-galactosidase is encoded by two overlapping genes. J Bacteriol 174, 4475-4481.

De Man, J. C., Rogosa, M. \& Sharpe, M. E. (1960). A medium for the cultivation of lactobacilli. J Appl Bacteriol 23, 130-135.

deVos, W. M. (1996). Metabolic engineering of sugar catabolism in lactic acid bacteria. Antonie Leenwenhoek 70, 223-242.

deVos, W. M., Boerrigter, I., van Roojen, R. J., Reiche, B. \& Hengstenberg, W. (1990). Characterization of the lactose specific enzymes of the phosphotransferase system in Lactococcus lactis. J Biol Chem 265, 22554-22560.

Dower, W. J., Miller, J. F. \& Ragsdale, C. W. (1988). High efficiency transformation of E. coli by high voltage electroporation. Nucleic Acids Res 16, 6127-6145.

Egeter, O. \& Brückner, R. (1996). Catabolite repression mediated by the catabolite control protein CcpA in Staphylococcus xylosus. Mol Microbiol 21, 739-749.

González-Candelas, L., Aristoy, M. C., Polaina, J. \& Flors, A. (1989). Cloning and characterization of two genes from Bacillus polymyxa expressing $\beta$-glucosidase activity in Escherichia coli. Appl Environ Microbiol 55, 3173-3177. 
Gräbnitz, F. \& Staudenbauer, W. L. (1988). Characterization of two $\beta$-glucosidase genes from Clostridium thermocellum. Biotechnol Lett 10, 73-77.

Hall, B. G. \& Xu, L. (1992). Nucleotide sequence, function, activation, and evolution of the cryptic asc operon of Escherichia coli K12. Mol Biol Evol 9, 688-706.

Helaszek, C. T. \& White, B. A. (1991). Cellobiose uptake and metabolism by Ruminococcus flavefaciens. Appl Environ Microbiol 57, 64-67.

Helfert, C., Gotsche, S. \& Dahl, M. K. (1995). Cleavage of trehalosephosphate in Bacillus subtilis is catalysed by a phospho- $\alpha-(1-1)-$ glucosidase encoded by the tre A gene. Mol Microbiol 16, 111-120.

Henrich, B., Monnerjahn, U. \& Plapp, R. (1990). Peptidase D gene (pepD) of Escherichia coli K-12: nucleotide sequence, transcript mapping and comparison with other peptidase genes. J Bacteriol 172, 4641-4651.

Henrissat, B. (1991). A classification of glycosyl hydrolases based on amino acid sequence similarities. Biochem J 280, 309-316.

Hueck, C. J., Hillen, W. \& Saier, M. H. (1994). Analysis of a cisactive sequence mediating catabolite repression in gram-positive bacteria. Res Microbiol 145, 503-518.

Kiewiet, R., Bron, S., de Jonge, K., Venema, G. \& Seegers, J. F. (1993). Theta replication of the lactococcal plasmid pWVO2. Mol Microbiol 10, 319-327.

Kok, J., van der Vossen, M. B. M. \& Venema, G. (1984). Construction of plasmid cloning vectors for lactic streptococci which also replicate in Bacillus subtilis and Escherichia coli. Appl Environ Microbiol 48, 726-731.

Krüger, S., Lindner, C. \& Hecker, M. (1996). Transcriptional analysis of bglPH expression in Bacillus subtilis : evidence for two distinct pathways mediating carbon catabolite repression. J Bacteriol 178, 2637-2644.

Leenhouts, K. J., Kok, J. \& Venema, G. (1990). Stability of integrated plasmids in the chromosome of Lactococcus lactis. Appl Environ Microbiol 56, 2726-2735.

Marasco, R., Muscariello, L., Varcamonti, M., De Felice, M. \& Sacco, M. (1998). Expression of the bglH gene of Lactobacillus plantarum is controlled by carbon catabolite repression. J Bacteriol 180, 3400-3404.

Miller, J. (1972). Experiments in Molecular Genetics. Cold Spring Harbor, NY: Cold Spring Harbor Laboratory.

Okamoto, T. \& Morichi, T. (1979). Distribution of $\beta$-galactosidase and $\beta$-phosphogalactosidase activity among lactic streptococci. Agric Biol Chem 43, 2389-2390.

Parker, L. L. \& Hall, B. (1990). Mechanisms of activation of the cryptic cel operon of Escherichia coli. Genetics 124, 473-482.

Premi, L., Sandine, W. E. \& Elliker, P. R. (1972). Lactosehydrolyzing enzymes of Lactobacillus species. Appl Microbiol 24, 51-57.

Raleigh, E. A., Murray, N. E., Revel, H., Blumenthal, R. M., Westaway, D., Reith, A. D., Rigby, P. W. J., Elhai, J. \& Hanahan, D. (1988). McrA and McrB restriction phenotypes of some E. coli strains and implications for gene cloning. Nucleic Acids Res 16, 1563-1575.

Reizer, J. (1989). Regulation of sugar uptake and efflux in grampositive bacteria. FEMS Microbiol Rev 63, 149-156.

Rixon, J. E., Hazlewood, G. P. \& Gilbert, H. J. (1990). Integration of an unstable plasmid into the chromosome of Lactobacillus plantarum. FEMS Microbiol Lett 71, 105-110.
Saier, M. H., Jr, Chauvaux, S., Cook, G. M., Deutscher, J., Paulson, I. T., Reizer, J. \& Ye, J. J. (1996). Catabolite repression and inducer control in gram-positive bacteria. Microbiology 142, 217-230.

Sambrook, J., Fritsch, E. F. \& Maniatis, T. (1989). Molecular Cloning: a Laboratory Manual, 2nd edn. Cold Spring Harbor, NY : Cold Spring Harbor Laboratory.

Schaefler, S. (1967). Inducible system for the utilization of $\beta$ glucosides in Escherichia coli I. Active transport and utilization of $\beta$-glucosides. J Bacteriol 93, 254-263.

Schnetz, K. \& Rak, B. (1988). Regulation of the $b g l$ operon of Escherichia coli by transcriptional antitermination. EMBO J 7, 3271-3277.

Schnetz, K., Toloczyki, C. \& Rak, B. (1987). $\beta$-Glucoside (bgl) operon of Escherichia coli K12: nucleotide sequence, genetic organization and possible evolutionary relationship to regulatory components of two Bacillus subtilis genes. J Bacteriol 169, 2579-2590.

Simons, G., Nijhuis, M. \& deVos, W. M. (1993). Integration and gene replacement in the Lactococcus lactis lac-operon: induction of a cryptic phospho- $\beta$-glucosidase in LacG-deficient strains. $J$ Bacteriol 175, 5168-5175.

Spector, T. (1978). Refinement of the coomassie-blue method of protein quantitation. Anal Biochem 86, 142-146.

Stülke, J., Arnaud, M., Rapoport, G. \& Martin-Verstraete, I. (1998). PRD - a protein domain involved in PTS-dependent induction and carbon catabolite repression of catabolic operons in bacteria. Mol Microbiol 28, 865-874.

Tobisch, S., Glaser, P., Krüger, S. \& Hecker, M. (1997). Identification and characterization of a new $\beta$-glucoside utilization system in Bacillus subtilis. J Bacteriol 179, 496-506.

Tyler, B. \& Magasanik, B. (1969). Molecular basis of transient repression of $\beta$-galactosidase in Escherichia coli. J Bacteriol 97, 550-556.

Vaughan, E. E., David, S. \& deVos, W. M. (1996). The lactose transporter in Leuconostoc lactis is a new member of the LacS subfamily of galactoside-pentose-hexuronide translocators. Appl Environ Microbiol 62, 1574-1582.

Wagner, E., Marcandier, S., Egeter, O., Deutscher, J., Götz, F. \& Brückner, R. (1995). Glucose kinase-dependent catabolite repression in Staphylococcus xylosus. J Bacteriol 177, 6144-6152.

Weber, B. A., Klein, J. R. \& Henrich, B. (1998). The arbZ gene from Lactobacillus delbrueckii subsp. lactis confers to Escherichia coli the ability to utilize the $\beta$-glucoside arbutin. Gene 212, 203-211.

Weickert, M. J. \& Chambliss, G. H. (1990). Site-directed mutagenesis of a catabolite repression operator sequence in Bacillus subtilis. Proc Natl Acad Sci USA 87, 6238-6242.

Witt, E., Frank, R. \& Hengstenberg, W. (1993). 6-Phospho- $\beta$ galactosidases of Gram-positive and 6-phospho- $\beta$-glucosidase B of Gram-negative bacteria : comparisons of structure and function by kinetic and immunological methods and mutagenesis of the lacG gene of Staphylococcus aureus. Protein Eng 6, 912-920.

Woodward, J. \& Wiseman, A. (1982). Fungal and other $\beta$-Dglucosidases - their properties and applications. Enzyme Microb Technol 4, 73-79.

Ye, J. J. \& Saier, M. H., Jr (1996). Regulation of sugar uptake via the phosphoenolpyruvate-dependent phosphotransferase system in Bacillus subtilis and Lactococcus lactis is mediated by ATPdependent phosphorylation of seryl residue 46 in HPr. J Bacteriol 178, 3557-3563.

Received 29 March 2000; accepted 28 April 2000. 